\title{
Orange rust in sugarcane - molecular identification in Rio de Janeiro State
}

\author{
Carla Vanessa Borges Castro ${ }^{1,3}$; Evaristo Vieira Mezavilla ${ }^{2}$; Paulo Sergio Torres Brioso ${ }^{1,4}$
}

${ }^{1}$ Laboratorio Oficial de Diagnostico Fitossanitário (L.O.D.F.), Área de Fitopatologia/ IB/ UFRRJ, Caixa Postal 74585, CEP 23897-970, Seropédica, RJ, Brasil; ${ }^{2}$ Secretaria de Estado de Agricultura e Pecuária - SEAPEC/ Defesa Sanitária Vegetal/ NDA - Campos; ${ }^{3}$ Bolsista CAPES/ UFRJ; ${ }^{4}$ Bolsista $\mathrm{CNPq}$

Autor para correspondência: Paulo Sergio Torres Brioso (brioso@bighost.com.br)

Data de chegada: 31/01/2012. Aceito para publicação em: 18/07/2013.

\section{ABSTRACT}

Castro, C.V.B.; Mezavilla, E.V.; Brioso, P.S.T. Orange rust in sugarcane - molecular identification in Rio de Janeiro State. Summa Phytopathologica, v.39, n.3, p.207-210, 2013.

Sugarcane (Saccharum spp.) cultivation is one of the major agricultural activities in the Brazilian states. This study aimed to molecularly identify the pathogen associated with rust in sugarcane cultivars in the state of Rio de Janeiro and to suggest a control strategy. Among the 14 PCR-tested cultivars, Puccinia kuehnii infection was identified for RB947520, RB92606, RB835486, RB72454, SP89-
11I5, SP83-2847, both from infected leaf sample and from urediniospores. Puccinia kuehnii was not detected by PCR for the cultivars RB955971, RB951541, RB92579, RB867515, RB855536, SP91-1049, SP80-3280, SP80-1816. This is the first molecular detection of this fungus in the state of Rio de Janeiro for six of the 14 analyzed cultivars.

Additional keywords: Puccinia kuehnii, Puccinia melanocephala, Poaceae, PCR.

\section{RESUMO}

Castro, C.V.B.; Mezavilla, E.V.; Brioso, P.S.T. Ferrugem Laranja da cana-de-açúcar - identificação molecular no Estado do Rio de Janeiro. Summa Phytopathologica, v.39, n.3, p.207-210, 2013.

O cultivo da cana-de-açúcar (Saccharum spp.) é uma das principais atividades agrícolas nos estados brasileiros. O presente trabalho teve por objetivos identificar molecularmente o patógeno associado à Ferrugem em cultivares de cana-de-açúcar no Estado do Rio de Janeiro e, sugerir estratégia de controle. Dentro das 14 cultivares testadas, através do teste de PCR, identificou-se a infecção de Puccinia kuehnii nas cultivares
RB947520, RB92606, RB835486, RB72454, SP89-1115, SP83-2847, tanto a partir de amostra foliar infectada como de urediniosporo. Não foi detectado P. kuehnii, através de PCR, nas cultivares RB955971, RB951541, RB92579, RB867515, RB855536, SP9I-1049, SP80-3280, SP80-1816. Trata-se da primeira detecção molecular deste fungo no Estado do Rio de Janeiro, em seis cultivares das 14 analisadas.

Palavras-chave adicionais: Puccinia kuehnii, Puccinia melanocephala, Poaceae, PCR.

The sugarcane (Saccharum spp.), according to Lima et al. (8), is a perennial grass belonging to the genus Saccharum, tribe Andropogoneae, family Poaceae (Gramineae). It is from Southeast Asia and constitutes the main raw material for the manufacture of sugar and alcohol (ethanol). In short, this culture produces high green matter yield, energy and fiber and is considered one of the plants with highest photosynthetic efficiency. Large-scale planting of sugarcane is traditional in many countries of tropical and subtropical regions for the production of sugar, alcohol and other by-products.

In all Brazilian states, cultivation of this plant is generally one of the main agricultural activities.

In Rio de Janeiro, according to Emater-Rio data of 2009 (4), $122,452.52$ ha of sugarcane were collected and approximately $54 \%$ were from the city of Campos dos Goytacazes. In this state, five species of bacteria, eleven species of fungi, seven species of straminipilous fungi and one species of virus have been cited so far as plant pathogens affecting sugarcane $(2,3)$.

Among the fungi listed in the state of Rio de Janeiro for sugarcane $(2,3,10)$, the most important ones are those that cause the diseases called Brown (caused by Puccinia melanocephala Syd. \& P. Syd.) and Orange Rust [caused by Puccinia kuehnii (W. Kruger) E. J. Butler]. The latter disease, first mentioned in Southeast Asia and Oceania in 1890, was spread to the world (11). Until 2008, its etiological agent was considered a quarantine pest absent in Brazil, according to the "Ministério da Agricultura, Pecuária e Abastecimento" (MAPA), the second list published in the Official Gazette of July 2008 (5, 13). However, its presence was confirmed in 2009 initially in the state of São Paulo (1) and later in the states of Espirito Santo, Goiás, Paraná (5), Mato Grosso do Sul, Minas Gerais (9) and Rio de Janeiro (Silvaldo Felipe da Silveira -2010, personal communication).

According to Glynn et al. (7), economic losses caused by the outbreak of the causative agent of Orange Rust in sugarcane in Australia were of the order of 150 to 200 million Australian dollars. In Brazil, according to MAPA, this disease caused a loss of one billion dollars (6) and its incidence in susceptible cultivars is known to potentially reduce the national productivity by at least $22 \%$ to $37 \%(6,12)$. This loss is caused due to a large number of injuries affecting leaves, impairing the photosynthesis and harming the development and, 
consequently, the productivity of leaves in terms of sucrose accumulation.

At the morphological level, the urediniospore related to Orange and Brown Rust has phenotypic differences (in terms of color and shape); however, the symptoms may vary depending on the infection duration, the location and the cultivar, which can lead to misidentifications (7). It is also noteworthy that at the field level rust formation can only be detected after urediniospore pustules are seen; in the early stages, the symptoms can be confused with those of another pathogen, e.g, Cercospora longipes E. J. Butler (5).

In addition, the identification becomes problematic when the number of spores is small, as is the case for samples from soil or water (7). In Brazil, P. kuehii was cited in the state of São Paulo for cultivars RB72454, SP84-2025, SP89-1115 and later in the state of Espírito Santo for cultivars RB72454, RB92606, and SP89-1115, clone CT 96-3415, as well as in Goiás for the cultivar RB72454, in Paraná for clones and CV 96-3415 TC 14, and in Rio de Janeiro and Minas Gerais for the cultivar RB72454 $(1,5,9)$.

Thus, specific molecular identification from infected leaf tissue or from spores of the fungus associated with Orange Rust in sugarcane by a sensitive, rapid and accurate test allows ready differentiation from other pathogens, rapid evaluation of susceptibility and resistance of sugarcane cultivars to $P$. kuehnii, possible presence of alternative hosts to the fungus, and immediate identification of the pathogen in several counties and/or Brazilian States using different types of samples (water, spores, soil, leaf tissue) at small quantities.

This study aimed to molecularly identify the pathogen associated with rust in sugarcane cultivars from the state of Rio de Janeiro by using both infected leaf sample, showing symptoms or not, and spores, as well as to suggest a control strategy.

Leaf samples from different cultivars (Table I), with or without symptoms (spots on the ventral surface and / or pustules on the dorsal surface; Figure 1A), were collected from March to June 2011 in Campo dos Goytacazes (RJ); they were placed in a paper envelope and sent to the Mycology Laboratory/ L.O.D.F./ IB/ UFRRJ. Then, they were analyzed under a binocular brand Wild M-5 (120 X) stereomicroscope to visualize the presence or the absence of the urediniospore associated with the pustules. As a control sample, sugarcane leaves collected in Seropédica (RJ), healthy or infected only with Leptosphaeria sacchari, were used $(2,3)$.

The morphological identification of fungal structures (uredia and urediniospore) was made under a binocular optical microscope Olympus CX40 (200 X) in semi-thin sections, done with the aid of sharp steel blade (Razor), of infected leaf tissue. The sectioned leaves were mounted on a microscope slide, covered with a cover slip in the presence of Amann lactophenol plus cotton blue $0.1 \%$ (w/v).

For DNA extraction, $100 \mathrm{mg}$ of fragment $(2 \times 4 \mathrm{~mm})$ of leaf tissue (infected or healthy) were deposited in a sterile mortar and placed with the aid of a sterile pestle under liquid nitrogen, added of $400 \mu \mathrm{L}$ buffer provided in the DNeasy Plant Mini Kit (Q1AGEN Brazil), followed by later instructions. The DNA was measured in a spectrophotometer for ultraviolet light and was diluted to a final concentration of $40 \mathrm{ng} . \mu \mathrm{L}^{-1}$.

Part of the observed urediniospore was transferred, with the aid of flamed stylus, to sterile polypropylene tubes and $1.5 \mathrm{~mL}$ of leaf samples was deposited in the Collection and Phytopathological Scientific Herbarium "Verlande Silveira Duarte" (UFRJ acronym - Index Herbarium, http://sweetgum.nybg.org/ih/herbarium.php?irn=126374).

For DNA extraction directly from the urediniospore, the latter was transferred, with the aid of flamed stylus, to sterile $1.5-\mathrm{mL}$ polypropylene tubes, which were added of liquid nitrogen by using a sterile glass pipette and left on ice for 30 seconds with the aid of an automatic homogenizer coupled to a sterile pistil to break the urediniospore until the complete elimination of liquid nitrogen. Then, $400 \mu \mathrm{L}$ of buffer provided in the DNeasy Plant Mini Kit (QIAGEN Brazil) was added by following the manufacturer's instructions. The DNA was measured in a spectrophotometer for ultraviolet light and was diluted to a final concentration of $40 \mathrm{ng} \cdot \mu \mathrm{L}^{-1}$.

PCR, followed by the procedure of Glynn et al. (7), was performed in a final volume of $100 \mu \mathrm{L}$ containing $2 \mu \mathrm{L}$ DNA, $0.25 \mathrm{mM}$ dNTPs, $2.5 \mathrm{mM} \mathrm{MgCl}, 0.5 \mathrm{mM}$ of each primer, 2.5 units of Taq DNA polymerase (Invitrogen) and $10 \mu \mathrm{L}$ of enzyme buffer $10 \mathrm{X}$. We used the primers PK1 -F: (sense) and PK1-R (reverse) specific for P. kuehnii and primers Pm1-F (sense) and Pm1-R (reverse) specific for $P$. melanocephala in separate tubes. The prepared tubes were placed in PTC 200 Thermocycler with an initial cycle at $94^{\circ} \mathrm{C}$ for five minutes, followed by 35 cycles of $94^{\circ} \mathrm{C}$ for $30 \mathrm{~s}, 56^{\circ} \mathrm{C}$ for $30 \mathrm{~s}, 72^{\circ} \mathrm{C}$ for $30 \mathrm{~s}$ and a final cycle at $72^{\circ} \mathrm{C}$ for seven minutes.

The amplified product was visualized after electrophoretic run in agarose gel containing $1 \%$ ethidium bromide $(10 \mathrm{mg} / \mathrm{mL})$ and photographed.

Of the collected leaf samples (Table 1), only six cultivars (RB947520, RB92606, RB835486, RB72454, SP89-1115, SP832847) from Campos dos Goytacazes (RJ) had pustules in formation or already broken, with the presence of urediniospore (Figure 1B), which is characteristic of Orange Rust, similarly to the descriptions made by Ferrari et al. (5). Other collected cultivars showed no symptoms or had symptoms without the presence of pustules.

By means of the adopted methodology, good quality DNA was obtained from both infected and healthy leaf tissue, as well as from the collected urediniospores.

The specific primers for P. kuehnii used in PCR resulted in an electrophoretic profile containing a fragment of about $527 \mathrm{bp}$, similar to that reported by Glynn et al. (7) both for the infected leaf tissue and for the urediniospore in six analyzed cultivars. On the other hand, the specific primers for P. melanocephala led to no amplification from both the infected leaf tissue and the urediniospore.

None of the used primers resulted in unspecific amplification of DNA from tissue that was healthy or infected with L. sacchari.

These data indicate, for the collected samples, the occurrence of simple infection within this $P$. kuehnii collection period although mixed infection with $P$. kuehnii and P. melanocephala may occur. According to several authors, Brown Rust is prevalent during the spring and Orange Rust in the wet summer period; however, Orange and Brown Rust can occur simultaneously, making it difficult to make field-level identification $(6,7)$.

Initially, the presence of the fungus in sugarcane (cultivar RB72454) in the municipality of Campos dos Goytacazes (RJ) occurred near the boundary with the state of Espirito Santo, indicating that the infested pathogen spores were from propagation material from this state or had been spread by the wind. This hypothesis is more plausible in relation to other susceptible cultivars (RB947520, RB92606, RB835486, SP89-1115, SP83-2847) planted in this country in the state of Rio de Janeiro.

In 2010, "Rede Interuniversitária para Desenvolvimento do Setor Sucroalcooleiro" (RIDESA) provided information on 91 sugarcane cultivars from RB (Republic of Brazil) (14); however, the resistance or susceptibility to P. kuehnii was not assessed for most of them. In 2011, some sugarcane cultivars resistant to P. kuehnii were reported for the state of Sao Paulo, according to the scale of disease severity 
Table 1. List of sugarcane cultivars, from Campos dos Goytacazes (RJ), with leaves showing symptoms or not.

\begin{tabular}{llll}
\hline Cultivar & Symptom* & $\begin{array}{c}\text { Presence of } \\
\text { uredia and } \\
\text { urediniospores }\end{array}$ & $\begin{array}{c}\text { PCR Reaction } \\
\text { with specifics } \\
\text { primers for } \\
\text { Puccinia Kuehnii }\end{array}$ \\
\hline RB955971 & M & Negative & Negative \\
RB951541 & M & Negative & Negative \\
RB947520 & M,P & Positive & Positive \\
RB92606 & M,P & Positive & Positive \\
RB92579 & M & Negative & Negative \\
RB867515 & M & Negative & Negative \\
RB867515 & Absent & Negative & Negative \\
RB855536 & M & Negative & Negative \\
RB835486 & M,P & Positive & Positive \\
RB72454 & M,P & Positive & Positive \\
SP91-1049 & M & Negative & Negative \\
SP89-1115 & M,P & Positive & Positive \\
SP83-2847 & Absent & Negative & Negative \\
SP80-3280 & M & Negative & Negative \\
SP80-1816 & M & Negative & Negative \\
Unknown & M, P & Positive & Positive \\
Unknown** & M & Negative & Negative \\
\hline
\end{tabular}

*M -Spot on the ventral leaf surface, $\mathrm{P}-$ Pustule on the dorsal leaf surface, ** from Seropédica (RJ) and infected with Leptosphaeria sacchari.
(9), including SP79-1011, SP80-1816, SP80-1842, SP80-3280, SP8I3250, SP83-2847, SP91-1049, RB835486, RB855453 and RB855536. For the state of Rio de Janeiro, however, the fungus is present but, to date, there are no data similar to those available for São Paulo State.

The data obtained in the present study (Table 1) evidence possible resistance to $P$. kuehnii isolate from the city of Campos dos Goytacazes (RJ) for different cultivars (RB955971, RB951541, RB92579, RB867515, RB855536, SP91-1049, SP80-3280, SP80-1816), in particular, RB867515. This cultivar is currently one of the most frequently planted in the region of Campos dos Goytacazes, although there have been more than 39 cultivars in this region since 2010 .

It is also confirmed that the diagnosis based only on the presence of the symptom (Table 1) can lead to misidentification, in accordance with the statements made above by Ferrari et al. (5) and Glynn et al. (7).

As a control strategy to be implemented in the state of Rio de Janeiro, it can be suggested: (i) survey, monitoring and identification of $P$. kuehnii, mainly at nursery, through molecular test in the various districts of this State, (ii) choice for planting sugarcane cultivars that are resistant, productive and adapted to the state of Rio de Janeiro associated with the progressive elimination of susceptible cultivars, and (iii) implementation of a spatial map of favorable germination of P. kuehnii spores similar to that for São Paulo State $(6,9,15)$.

This study shows the first molecular detection of $P$. kuehnii in the state of' Rio de Janeiro for the analyzed cultivars, describing the Official Laboratory of Phytossanitary Diagnosis/UFRRJ, accredited by MAPA and belonging to the National Network of Agricultural Laboratories of the Unified System for Agricultural Health Care, as one of the laboratories in the country with competence to issue reports
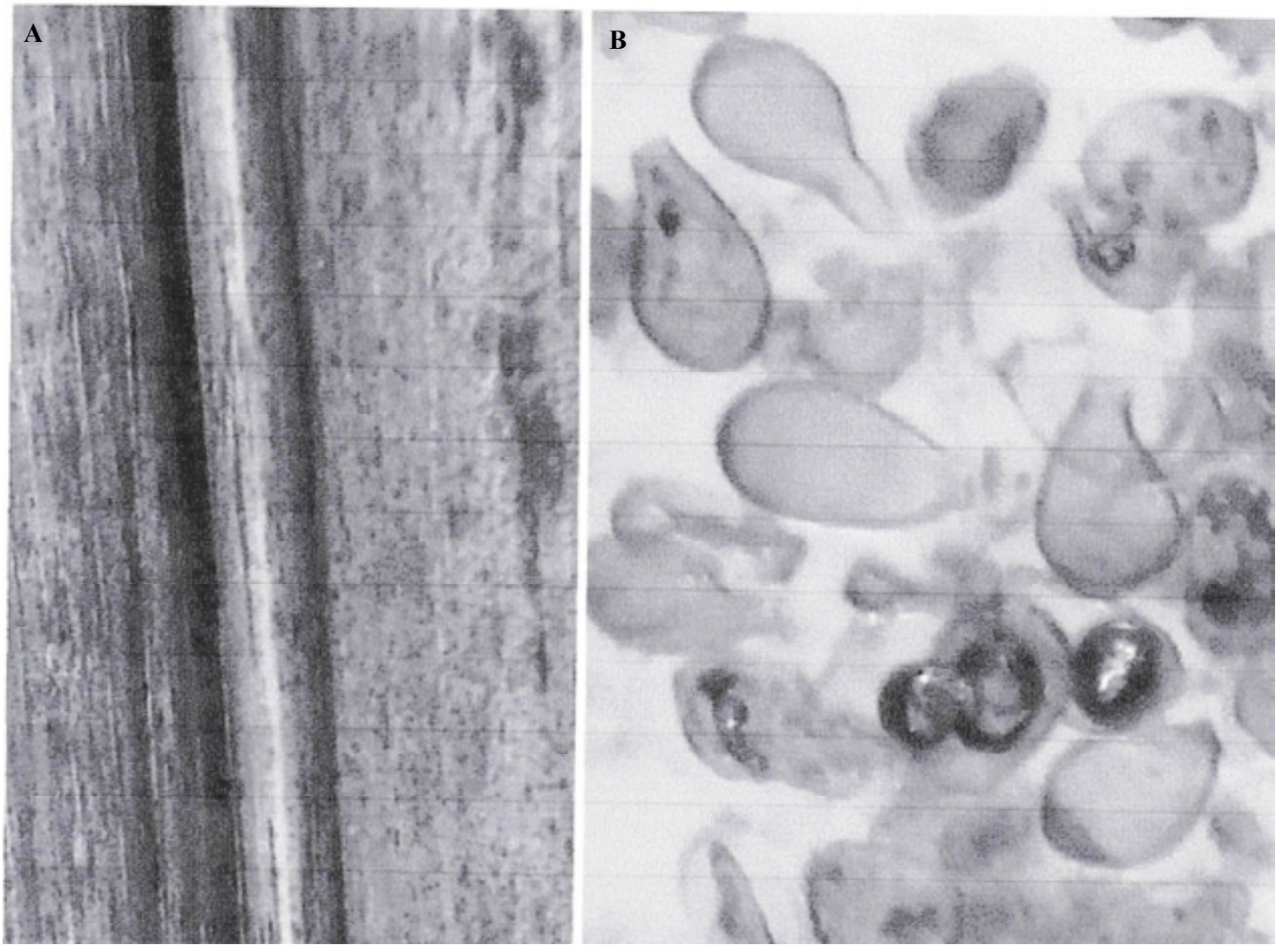

Figure 1. Orange Rust of sugarcane (Saccharum spp.) cultivar RB72454: A- leaf pustules (left), B - Detail of urediniospore under optical microscope (right). 
concerning this pathogen. Besides, it allows producers to direct sugarcane planting in the state of Rio de Janeiro for periods less conducive to the pathogen associated with Orange Rust combined with the planting of resistant cultivars; these data also promote sugarcane improvement for showing a sensitive, rapid and secure method for the detection of $P$. kuehnii.

\section{ACKNOWLEDGEMENTS}

The authors are grateful to Lúcio Soares, Jair Felipe Garcia Pereira Ramalho and Aldo Jabes Alves Aguiar for their assistance in the collection and identification of sugarcane cultivars.

\section{REFERENCES}

1. Barbasso, D.; Jordao, H.; Maccheroni, W.; Boldini, J.; Bressiani, J.; Sanguino, A. First report of Puccinia kuehnii, causal agent of Orange Rust of sugarcane, in Brazil. Plant Disease, St. Paul, v.94, n.9, p.1170, 2010.

2. Castro, C. V. B.; Brioso, P. S. T. Cana-de-açúcar (Saccharum spp.) e fitopatogenos correlacionados. $201 \mathrm{I}$. Disponivel $\mathrm{cm}$ : $<$ http://www.fito2009.comicana/>. Acesso ern: 30 de julho de 2011.

3. Castro, C. V. B.; Brioso, P. S. T. Mancha Anelar em cana-de-ackar no Estado do Rio de Janeiro. Tropical Plant Pathology, Brasilia, v.36, supl., 2011

4. Emater-Rio. ASPAS - Acompanhamento sistemitico da Produção Agrícola. 2011. Disponivel em: <http:// wwwematerrigov.britecnica.asp>. Acesso em: 30 de julho de 2011.

5. Ferrari, J. T.; Harakava, R.; Domingues, R. J.; Tercariol, I. M. L. Ferrugem alaranjada da cana-de-açúcar. Documento Técnico do Instituto Biologico - APTA,Campinas, n.5, p.1-8, 2010.

6. Giglioti, E. A. Mapeamento da favorabilidade e sistema de monitoramento, aviso e orientacao para o controle integrado da ferrugem alaranjada (Puccinia kuehnii) da cana-de-açúcar no Brasil. Summa Phytopathologica, Botucatu, v.36, supl., 2010.

7. Glynn, N. C.; Dixon, L. J.; Castlebury, L. A.; Szabo, L. J.; Comstock, J. C. PCR 132 assays for the sugarcane rust pathogens Puccinia kuehnii and P. melanocephala and detection of a SNP associated with geographical distribution in P. Kuehnii. Plant Pathology, UK, v.59, p.703-711, 2010.

8. Lima, M. A. C.; Garcia, R. 0.; Martins, G. S.; Mansur, E. Morfogenese in vitro e susceptibilidade de calos de variedades nacionais de cana-de-açúcar (Saccharum officinarum L.) a agentes seletivos utilizados em sistemas de transformacao genetica. Revista Brasileira de Botanica, Sao Paulo, v.24, n.1, p.7377, 2001.

9. Martins, T. D. Aspectos epidemiológicos da ferrugem alaranjada da cana-de-açúcar. 2010.65 f. Dissertação (Mestrado em Fitopatologia) - Escola Superior de !41 Agricultura "Luiz de Queiroz"/ USP, Piracicaba, SP.

10. Mendes, M. A. S.; Silva, V. L.; Dianese, J. C.; Ferreira, M. A. S. V.; Santos, C. E. N.; Gomes Neto, E.; Urben, A. F.; Castro, C. Fungos em plantas no Brasil. Brasília: Embrapa-SP1/ EmbrapaCenargen, 1998. $569 \mathrm{p}$.

11. Ministério da Agricultura, Pecuária e Abastecimento. Ferrugem Alaranjada !43 (Puccinia kuehnii) 2010. Disponível em: <http:/ /www.agricultura.gov.br/arq_editor/file/MAIS DESTAQUES/ Ferrugem Alaranjada.pdf/>. Acesso em: 30 de julho de 2011.

12. Moreno, A. Nova doença pode ameaçar canaviais brasileiros. Jornal Cana, n. 250 setembro, p.52, 2008.

13. Oliveira, C. S. Mendes, M. A. S. Puccinia kuehnii. um risco para a cultura de cana-de-açúcar no Brasil. Comunicado Técnico da Embrapa, Brasília, 11.184, p.1-5, 2008.

14. Rede Interuniversitária para Desenvolvimento do Setor Sucroalcooleiro (RIDESA). Catálogo nacional de variedades "RB" de cana-de-açúcar. Curitiba Rede 256 Interuniversitária para Desenvolvimento do Setor Sucroalcooleiro, 2010.136p.

15. SCORARLET. Rede de alerta para a prevenção de perdas causadas pela Ferrugem Alaranjada (Puccinia kuehnii) da cana-de-açúcar no Brasil. 2010. Disponível em: <http:// kvww.scoralert.com.br/>. Acesso em: 30 de julho de 2011 . 